\title{
SYMPOSIUM ON THE AMERICAN CONVENTION ON HUMAN RIGHTS AND ITS NEW INTERLOCUTORS
}

\section{WHEN ILLIBERALS EMBRACE HUMAN RIGHTS}

\author{
Alexandra Huneeus*
}

A topic motivating much research since 2016 is the turn away from international law caused by a surge in nonliberal and nationalist governments across the world. In the realm of human rights law, scholars have noted how states are now more apt to repudiate, resist, or simply ignore their human rights obligations. This essay makes a different cut into this topic. It considers not how non-liberal actors reject human rights law, but rather what happens when they embrace it. International human rights law in Latin America—often understood as a means of promoting a cosmopolitan, liberal political order - is also being harnessed toward other types of political projects. This raises the question of how necessary the link is between human rights and political liberalism: ${ }^{1}$ is non-liberal engagement an existential threat, or can human rights law have a thinner commitment to liberal principles than does, for example, national constitutional law? As the American Convention on Human Rights (ACHR) turns fifty, this essay argues that the human rights law of the Americas is open-ended enough that it can incorporate, and has at times incorporated, non-liberal concerns and norms without losing coherence or legitimacy. Further, this may be an apt survival strategy, albeit not the only one, for the region's human rights institutions in our time.

\section{Illiberal Engagement with Human Rights Law}

It can be tempting to minimize non-liberal engagement with human rights as politicized and therefore somehow disingenuous, or as a feature of contemporary politics. But this view is incomplete; the engagement of non-liberal governments with human rights law is neither new nor purely strategic. At the UN level, the construction of human rights instruments and institutions was shaped in part by the contest between the United States and the Soviet Union and their respective allies, as well as by North-South tensions. From the very beginning, communist governments and other non-liberal states helped codify and institutionalize human rights, and economic and social rights in particular.

At the regional level of human rights protection, the early history is different: human rights law and discourse in the European and American systems were closely tied to political liberalism. Both systems were created in part to

\footnotetext{
* Professor of Law and Director of Global Legal Studies Center, University of Wisconsin Law School.

1 "Political liberalism" here is used in the classic sense of a political theory or practice that prioritizes individual liberty and limited government, such that encroachments on liberties must be justified in terms of individual liberty. Liberal societies are characterized by constitutionalism, democracy, equal rights, and the rule of law. The term "non-liberal" refers to all governments, ranging from authoritarian to socialism to communism, that prioritize projects other than individual liberty.
}

(C) Alexandra Huneeus 2019. This is an Open Access article, distributed under the terms of the Creative Commons Attribution licence (http://creativecommons.org/licenses/by/4.0/), which permits unrestricted re-use, distribution, and reproduction in any medium, 
denote a moral difference with communism, and both expressed a commitment to liberal democracy. ${ }^{2}$ Like the European Convention on Human Rights, the ACHR prioritizes civil and political rights.

Further, the politics at the regional level were at times more unified, allowing the regional systems to develop more quickly, and they did so in the direction of liberal legality. During the 1950s and early 1960s, as the UN System was stymied by Cold War politicking, the Americas enjoyed a period of democracy, and members of the Organization of American States (OAS) created the Inter-American Commission and embarked on writing the ACHR. ${ }^{3}$ In the 1990s, as the region returned to democracy after a period of dictatorships, there was enough political cohesion to allow the further development of the Inter-American System (IAS). At this juncture, the IAS - like the European human rights system and in contrast to human rights at the UN-became focused on individual petitions and litigation. Further, Latin American courts began to cite to IAS corpus iuris and to review domestic laws and acts under international human rights law, especially the ACHR. Indeed, over the past two decades, perhaps the most significant development in international human rights law in the Americas has been its entwinement with constitutional rights. ${ }^{4}$

What is distinctive about non-liberal engagement with human rights in our time, therefore, is not that it exists, or that it is at times strategic. ${ }^{5}$ At the level of the regional systems, the novelty is rather that non-liberal engagement with human rights means engagement with liberal legality—with courts that exercise judicial review and with the doctrines of liberal constitutionalism. Thus emerge unusual hybrids, such as human rights doctrines fashioned by courts that openly view themselves not as removed from politics but as advancing a particular emancipatory political project, and social movements that expand rights protection beyond the individual, to include culturally defined groups and even non-human entities such as forests and rivers.

These forms of engagement are double-edged. At one extreme, they can be an example of covert-or thinly veiled-resistance to human rights obligations. They can be akin to abusive constitutionalism, in which constitutional law is used to make a state "significantly less democratic than it was before." 6 At the other extreme, they can be an example of creative engagement that attempts to widen the reach and vocabulary of human rights law. What follows below is an exploration of each extreme. This is not yet an attempt to build a typology, but rather a reflection on two cases that bring out the range and richness of non-liberal political engagement with human rights.

\section{The Bolivian Battle over Term Limits}

A 2017 judgment of the Bolivian Constitutional Court — the Plurinational Constitutional Tribunal (PCT)—used the ACHR to strike down constitutionally mandated term limits. Bolivian President Evo Morales was first elected to office in 2006, the first Bolivian president of indigenous identity. He came into office with a promise to renew and decolonize Bolivian politics and oversaw a constituent assembly that promulgated a new constitution in 2009. The new constitution lifted a ban on presidents serving consecutive terms (with each term running five years) but limited presidents to a total of two terms. Morales won his second presidential term in 2009, after the first was shortened due to the constituent assembly and new constitution. In 2013, the PCT ruled that Morales could run

\footnotetext{
${ }^{2}$ Alexandra Huneeus \& Mikael Rask Madsen, Between Universalism and Regional Law and Politics: A Comparative History of the American, European, and African Human Rights Systems, 16 InT'L J. Const. L. 136 (2018).

${ }^{3}$ Klaus Dykmann, Philanthropic Endeavors or the Exploitation of an Ideal? The Human Rights Policy of the Organization of American States in Latin America (1970-1991) (2004).

${ }^{4}$ Alexandra Huneeus, Introduction to Symposium on the Constitutionalization of International Law in Latin America, 109 AJIL UNBOUND 89 (2015).

${ }^{5}$ For a similar argument, see Alejandro Rodiles, Is There a Populist International Law (in Latin America)?, 49 NETH. Y.B. INT'L L. 69 (2019).

${ }^{6}$ David Landau, Abusive Constitutionalism, 47 U.C. Davis L. Rev. 189 (2013).
} 
for a third term because the first term had commenced prior to the new constitution. In 2016, Morales held a referendum on striking the term-limit provisions from the 2009 Constitution and lost by a narrow vote in what became a highly contested outcome.

In November of 2017, the PCT ruled that the term limits of the 2009 Constitution were unconstitutional, opening the way for Morales to seek a fourth term, and thus allowing his presidency to potentially span almost two decades (2006-2025). ${ }^{7}$ The PCT is appointed by popular election and considered to be partial and deferential to the Morales presidency. Domestic and international legal observers alike denounced the judgment. Further, the seventy-nine-page judgment is repetitive, thinly reasoned, and lacking in nuance. It is easily dismissed as a naked political gambit.

Yet the manner in which the judgment engaged human rights law deserves consideration. Perhaps the most striking aspect of this case was how readily the Court subverted Bolivia's own constitution to the ACHR. Following the Inter-American Court's doctrine of "conventionality control," the judgment declared that judges are bound to strike down laws-even constitutional laws - that are not in conformity with the ACHR, and that the judgments of the Inter-American Court are binding authority.

The Court's reading of the substantive content of the American Convention was idiosyncratic. Article 23 of the ACHR states, "Every citizen shall ... have access, under general conditions of equality, to the public service of his country." 8 This right can be restricted "only on the basis of age, nationality, residence, language, education, civil and mental capacity, or sentencing by a competent court in criminal proceedings." "The Court found that the Constitution's term limits do not fall within those exceptions, and therefore violate the Convention. But the Court did not consider the role of the 2016 referendum, which some Bolivian lawyers argue is binding notwithstanding the PCT judgment. Nor did it consider that rights must be balanced against each other, or that under its reading of Article 23 almost every constitution of the twenty states under the Inter-American Court's jurisdiction violates the Convention.

On the other hand, the Court's reading of the Inter-American Court's conventionality control doctrine seems consonant with the Inter-American Court's own understanding. Further, other regional courts have reached similar outcomes on the question of constitutional term limits using domestic rights interpretation. ${ }^{10}$ The difference here is that the judgment hinges almost entirely on the ACHR and conventionality control, and uses Bolivia's membership in the OAS human rights system as a way to legitimate its outcome-never mind that the OAS Secretary General himself immediately called the judgment a misreading of the ACHR.

A persistent feature of Latin American democracy has been the reluctance of leaders to step down at the end of their terms. The problem did not disappear with the spread of constitutional review in the 1990s, but it has taken on a more legalistic form. ${ }^{11}$ Such attempts now begin with a proposal to amend or reinterpret the constitutional term limits and are usually followed by a constitutional court judgment. In Bolivia, the ongoing struggle took a new turn, enlisting the ACHR and the Inter-American Court to justify perpetual presidencies. It seems clear that the Court and Commission will disavow this reading of the American Convention. But it is significant that the

\footnotetext{
7 Plurinational Constitutional Tribunal, Nov. 28, 2017, 0084/2017, Gaceta Plurinacional Constitucional (Bolivia).

8 American Convention on Human Rights ("Pact of San Jose, Costa Rica” (B-32)), Nov. 22, 1969, O.A.S.T.S. No. 36, 1144 UNTS 123; American Convention on Human Rights art. 23, Nov. 21, 1969, 1144 UNTS 143.

${ }^{9} \underline{I d}$.

${ }^{10}$ David Landau \& Brian Sheppard, The Honduran Constitutional Chamber's Decision Erasing Presidential Term Limits: Abusive Constitutionalism by Judiciary?, Int'L J. Const. L. Blog (May 6, 2015); see also Mauricio Guim \& Augusto Verduga, Is Ecuador Heading Towards a Constitutional Crisis?, Int'L J. Const. L. Blog (Nov. 1, 2017).

${ }^{11}$ David Landau et al., Term Limits and the Unconstitutional Constitutional Amendment Doctrine: Lessons from Latin America, in PoLITICs OF Presidential Term Limits (Alexander Baturo \& Robert Elgie eds., forthcoming).
} 
challenge to the substance of Article 23 comes couched in an opinion that evinces the strongest possible version of conventionality control even as it echoes other national high courts in the region on the subject of term limits.

\section{The Rise of Eco-centric Rights}

The second example shows a different way in which non-liberal polities participate in and contribute to the evolution of human rights law. In 2008, Ecuadorans promulgated the first constitution to contain ecocentric rights - rights that protect ecosystems and natural bodies as ends in themselves, and not only as a means to foster human well-being. ${ }^{12}$ The idea of ecocentric rights in Latin America claims its roots in indigenous world views that decenter the human and emphasize the ethical relation between human and non-human entities. In other words, the doctrine springs from non-Western and non-liberal worldviews. It also threatens to interfere with the core liberal concern of an individual right to property.

The idea has since spread to a handful of jurisdictions around the world, at different levels of law and with varying success. In Evo Morales's Bolivia, for example, the administration embraced the idea, spearheading legislation that endows nature with rights and establishes legal mechanisms for its protection. At the time that both Bolivia and Ecuador were enunciating ecocentric rights, they were led by non-liberal governments, and the rights were established through legislation and constituent assemblies rather than through judicial means.

But these rights have spread to liberal democratic states as well. Most notably, Colombian courts have endowed several rivers, an Andean plateau, and the Amazon basin with rights under the 1991 Colombian Constitution. ${ }^{13}$ These rights, moreover, have been established by not only the Colombian Constitutional Court, which is known in the region for its creative rights jurisprudence, but also the Colombian Supreme Court. Beyond Latin America, attempts to protect rivers by declaring them to be rights-bearing persons have been made in India, New Zealand, and the United States, although securing legal status only in New Zealand. The Inter-American Court has not incorporated ecocentric rights into its jurisprudence, but it favorably takes note of the development in a recent advisory opinion. ${ }^{14}$

One might object that a development that seeks to decenter the human is not exactly an example of human rights innovation. It could be cast instead as a change that upends or transcends human rights. Note, however, that the same might have been said of the claims to autonomy raised by indigenous groups starting in the 1970s. This, too, was an idea born of social movements in the Americas that did not prioritize political liberalism. The claim that cultural groups bear rights as groups similarly posed a conceptual challenge to the individual nature of human rights. However, in a series of ground-breaking judgments, the Inter-American Court read the ACHR's right to property to include the right of indigenous groups to collective ownership of traditionally-owned land. ${ }^{15}$ As in those cases, coalitions of traditional and new NGOs are seeking to broaden the doctrine to include a new type of rights-bearing person. In this way, non-liberal claims are advanced through the existing structures of human rights liberal legality.

\footnotetext{
12 Constitución Política De La República Del Ecuador art. 56-60.

13 See, e.g., Corte Constitucional de Colombia [Colombian Constitutional Court], Apr. 5, 2018, T-622/16, GaCeta de La Corte Constitucional [G.C.C.] (Colom.).

14 The Environment and Human Rights (State Obligations in Relation to the Environment in the Context of the Protection and Guarantee of the Rights to Life and to Personal Integrity - Interpretation and Scope of Articles 4(1) and 5(1) of the American Convention on Human Rights), Advisory Opinion OC-23/18, Inter-Am. Ct. H.R., (ser. A) No. 23 (Nov. 15, 2017).

15 See, e.g., Mayagna (Sumo) Awas Tingni Community v. Nicaragua, Merits, Reparations and Costs, Dissenting Opinion of Judge ad hoc Alejandro Montiel Argüello, Inter-Am. Ct. H.R. (ser. C) No. 79 (Aug. 31, 2001).
} 
Eco-centric rights doctrines are a recent and still liminal trend. They seem to be spreading, however, partly because they reflect a pervasive sense of environmental crisis, particularly due to climate change. That the right of mother earth was forged in the smithy of a Leftist constitutional assembly has not stopped it from permeating more liberal states. ${ }^{16}$

Regional Rights as Dynamic Systems

A full catalog of ways that non-liberals engage with human rights law in our time would have to include the efforts of these actors to directly undermine the regional rights system. The cases described above, however, add a new twist to the existing scholarship on illiberal backlash against human rights institutions. ${ }^{17}$ They are not examples of rejection but of working from within human rights institutions and doctrine to alter them, although in ways that do not comport with political liberalism. Taken together, the two cases suggest that rights forged within illiberal regimes can contribute to shaping human rights doctrine more generally, and can have impact - in the sense of altering politics. Further, like so much human rights activity in the region since the turn of the millennium, they are born of and entwined with constitutional law claims. For better or worse, non-liberals also believe in human rights (and also use them instrumentally) and their political activity takes on legal forms that use constitutionalism.

This is not to deny that some uses of human rights law have more integrity than others. The term-limits example appears on its face to be a misuse of the ACHR, as the meaning ascribed to the ACHR departs so far from the Convention's meaning and spirit in the existing corpus iuris. Indeed, that example embodies the most feared outcome: an "abusive"18 legalism that weaponizes human rights law and institutions against core liberal democratic practices. The ecocentric claims example, by contrast, shows that rights constructed by non-liberal political movements can spread to liberal constitutional systems, where they sit uneasily but, arguably, productively.

One might object that the only distinction between the two examples lies in the political preferences of the observer. To construct a typology of illiberal uses of human rights, one would have to argue for a principled distinction between these two cases, perhaps rooted in whether they threaten democracy. ${ }^{19}$ But the object here is more modest: to advance the argument that non-liberals do use human rights law effectively, and that this is not only an under-theorized threat from within but also an opportunity for enriching human rights law. Transformative ideas about justice that do not correspond with traditional liberal legality are not for that reason wrong or not human rights. ${ }^{20}$ As Sam Moyn argues, human rights as a set of ideals is in need of renovation. ${ }^{21}$

16 See generally Rodiles supra note 5 (discussing ecocentric rights as an example of populist international law).

17 See supra note 1.

18 See Landau, supra note 6.

19 See, e.g., id.

${ }^{20}$ Human rights law is not meant to lock in issues away from politics, but rather to "build dynamic systems" that "evolve the full meaning and concrete implications of the principles" they lay down, "in response to more or less broad coalitions of actors." Daniel M. BRINKS \& Abby Blass, The DNA of Constitutional Justice in Latin America: Politics, Governance, and Judicial Design 8 (2018).

${ }^{21}$ Samuel Moyn, Not Enough: Human Rights in an Unequal World (2018). 